\title{
$4^{\mathrm{TH}}$ INTERNATIONAL CONFERENCE OF ZAKAT PROCEEDINGS \\ ISSN: 2655-6251
}

\section{Factors that Affect the Performance of Amil}

\author{
Achmad Hizazi, Wirmie Eka Putra \\ Universitas Jambi \\ Paper to be presented at the $4^{\text {th }}$ International Conference of Zakat (ICONZ) \\ 7-8 October 2020, Surabaya, Indonesia
}

\begin{abstract}
ABSTRACK
We investigate the effect o amil fund, size of amil zakat (LAZ) and number of office to financial performance measured by fund collected. We run OLS with 41 observations from 10 amil Zakat (LAZ) from the year 2010 - 2019 with pool data. We find evidence that the increase of Amil would increase financial performance of amil zakat, however size of amil zakat only has marginal effect to financial performance of amil zakat. While number of offices doesn't have effect to financial performance.
\end{abstract}

Keywords: Finacial performance, Amil fund, size of LAZ and number of office.

\section{INTRODUCTION}

\section{Background}

Institutional zakat management in Indonesia began to develop after the reformation with the issuance of Law No. 38 on zakat management in 1999 , which was later replaced by Law No. 23 of 2011. Along with the managerial strengthening of zakat management, research on zakat management developed following the development of the zakat institution itself. So far, research on the performance of the Zakat Management Unit (LAZ) has not achieved satisfactory results. Apart from the incomplete coverage, this can be seen from the unsatisfactory results or the inappropriate research methods used.

Our motivation for this research is based on theoretical and practical foundations in performance research. Firstly, motive non-profit organizations such as the Zakat Management Unit (LAZ) lack a qualified performance measure (Kaplan 2001), which encourages researchers to look further the accuracy of the performance measures that have been used. Second, the existing research has mostly referred to the efficiency of institutional management (Ahmad \& Main,
2014; Mubtadi \& Susilowati, 2018; AlAyubi \& Possumah, 2018; Rustyani \& Rosyidi 2018; Risanda et. Al., 2018). Other existing performance measures refer to measures of macro-level performance of "local government" rather than the performance of LAZ institutions.

LAZ in Indonesia has two forms of management, namely the Amil Zakat Agency (BAZ) and the Amil Zakat Institute (LAZ). Due to the different formation processes, BAZ is a semi-autonomous body formed by the government and LAZ is formed by the community, in general there are differences in management and related subjects in the management of zakat. These differences in properties also make performance measures and their influencing factors different.

This research is expected to find appropriate performance measures to be used and to see the factors that influence financial performance both from a qualitative perspective through the perspective of zakat managers as well as from a quantitative side of testing between the variables being tested. Stake holders, both the government, zakat managers and 
other people, can see LAZ's performance better and make better performance comparisons. Stake holders can also pay attention to factors that enhance or hinder performance.

The results of research can be used as input for the Government funds or through National Development Planning Agency (Baznas) regarding the ideal performance measurement of LAZ and in determining standard reporting points that can be used as a reference in measuring the performance of the Institution.

From the background that has been previously described, in this study we examine the factors that affect the performance of amil zakat. The main problem discussed in this study is whether factors such as amil funds, amil size and number of offices affect the financial performance of zakat management units in Indonesia.

\section{LITERATURE REVIEW}

\section{Performance Measure}

Performance measurement is something that is very important for an institution to see the success of the institution. Commercial institutions have a very good measure of describing this because at least there are performance measures such as earnings and stock returns (Kaplan 2001) that non-commercial institutions do not have. Because of this nature, previous research in zakat institutions mostly used efficiency measures using the Data Enveloping Analysis method which was first formulated by Farel (1957). There is also a study that uses the production function measure with Stochastic Frontiers Analysis (SFA) following the Cobb Douglas production function with the receipt of zakat and its distribution as the dependent variable (Risanda et al., 2018), while Mubtadi and Susilowati (2018) use regression in testing efficiency. with governance as the independent variable.

\section{Amil Zakat Performance}

The performance variable with efficiency uses the ratio of input and output produced by zakat institutions. Performance variables that have been used in previous studies are as follows: Efficiency Measures: Distribution Efficiency (Mubtadi \& Susilowati, 2018; Al-Ayubi et al, 2018; Rustyani \& Rosyidi, 2018), technical efficiency (Risanda et. Al., 2018; Al-Ayubi et al (2018) and Measures of productivity by Rustyani \& Rosyidi (2018).

The number of input and output variables used shows the diversity of efficiency measures used by previous studies. The use of this variable may be subjective with user preferences as the main consideration. On the other hand, from the above research Mubtadi and and Susilowati and Risanda et al (2018) also conducted a regression test with the dependent variable Zakat collection and efficiency but the results were not satisfactory due to methodological limitations where Mubtadi and Susilowati (2018) only used 20 observations and Risanda. et al (2018) only used 15 observations whose results might be biased.

\section{Previous research}

From several performance alternatives from previous research (Ahmad \& Main, 2014; Mubtadi \& Susilowati, 2018; AlAyubi \& Possumah, 2018; Rustyani \& Rosyidi 2018; Risanda et. Al., 2018) such as Zakat Collection, Zakat Distribution, Zakat Recipients, Total Asset and the efficiency of Zakat collection is an alternative to the main performance measures because it is able to describe the maximum amount of zakat institution efforts to collect as much zakat as possible. Another alternative is the amount of infaq received, because zakat reflects an obligation that must be paid while infaq is voluntary. The higher the infaq value, the higher public trust in zakat institutions. 
Meanwhile, the variation of the distribution of zakat really depends on the size of the amount of zakat collected.

Tabel 1. The variable used in previous research.

\begin{tabular}{|c|c|c|c|}
\hline Researcher & Input (independent) & Output & Variable \\
\hline \multirow[t]{3}{*}{$\begin{array}{l}\text { Mubtadi \& Susilowati } \\
(2018)\end{array}$} & Collection of Zakat & Distribution of Zakat & $\begin{array}{l}\text { Distribution } \\
\text { Efficiency }\end{array}$ \\
\hline & Zakat Cost & Distribution of Zakat & Cost Efficiency \\
\hline & Time & Distribution of Zakat & Time Efficiency \\
\hline Risanda et al. (2018) & Collection of Zakat & Distribution of Zakat & technical Efficiency \\
\hline \multirow{2}{*}{$\begin{array}{l}\text { Rustyani \& Rosyidi } \\
\text { (2018) }\end{array}$} & Collection of Zakat & Distribution of Zakat & Efficiency \\
\hline & $\begin{array}{l}\text { Biaya Zakat } \\
\text { Dana Amil }\end{array}$ & Total Aset & Productivities \\
\hline \multirow[t]{3}{*}{ Al-Ayubi et al (2018) } & Amount of volunteer & Collection of Zakat & $\begin{array}{l}\text { Distribution } \\
\text { Efficiency }\end{array}$ \\
\hline & Amount of Amil & $\begin{array}{l}\text { Consumtive Distribution } \\
\text { of Zakat }\end{array}$ & technical Efficiency \\
\hline & $\begin{array}{l}\text { Sosialisation Cost } \\
\text { Salary } \\
\text { Operational Cost } \\
\text { Number of offices }\end{array}$ & $\begin{array}{l}\text { Productive Distribution of } \\
\text { Zakat }\end{array}$ & Total Efficiency \\
\hline
\end{tabular}

Framework and Research Model

Rustyani and Rosyidi (2018) explain that the distribution of funds will be affected by the amount of costs incurred and the amount received by Amil Zakat. Meanwhile, the distribution of funds will be influenced by the amount of Zakat collected by LAZ so that the Zakat collected will also be influenced by the amount of operational costs and the amount received by amil. Apart from these two factors, Al-Ayubi et al. (2018) Adding the number of volunteers and the number of offices as factors affecting the output of LAZ. Figure 1 shows the framework and research model.

Figure 1. Framework and research model

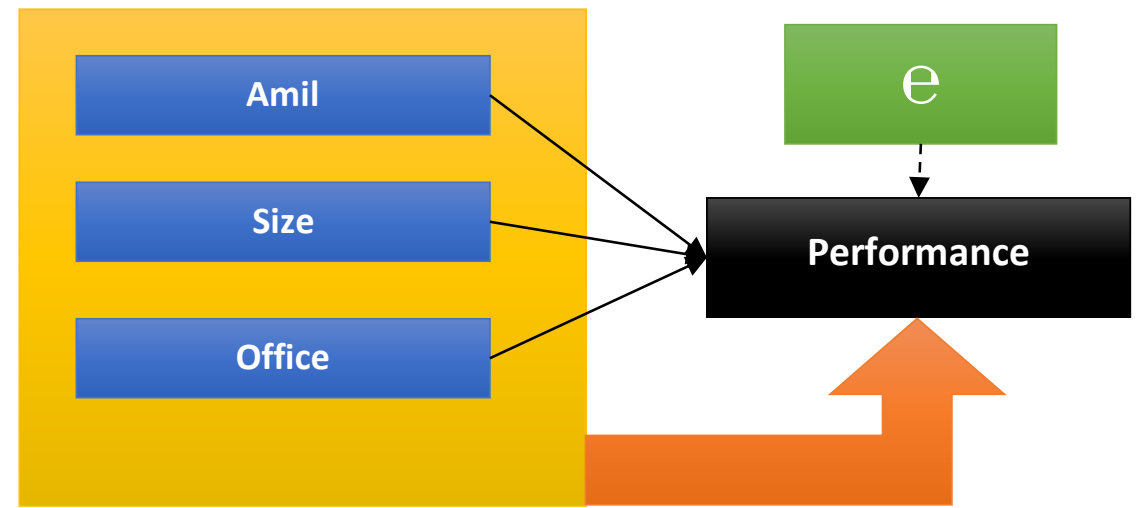

This research in the roadmap is part of a micro research that formulates a performance model of LAZ and the factors that influence it. Model formulation will be carried out in the first year. Model empirical testing was carried out in the first year for 17 National LAZs starting with data collection from the field, then model modification was carried out in the second year with empirical testing carried out with 
450 BAZNAS subjects throughout Indonesia. This research On the Roadmap is located in the Micro Focus marked with a shaded box.

\section{Research Hipotesis}

Based on the literature review, previous research as well as the framework and research model above, the hypothesis of this study is as follows:

H1: Amil Fund has a positive effect on LAZ zakat collection

$\mathrm{H} 2$ : The size of LAZ has a positive effect on LAZ zakat collection

H3: Number of offices partially influences the collection of zakat LAZ

\section{RESEARCH METODE}

This research uses quantitative methods using multiple regression. The variables to be examined in this study are the provision of Amil Funds, the Size of LAZ and the Number of Offices as well as the Total Fund Collected.

\section{Research Data and sample}

The data used are the amount of revenue, amil funds, number of offices, and total assets, from 2010 to 2019. data on revenue, amil funds and total assets are collected from financial reports published by the amil zakat institution on the LAZ website. Each session has a different number of observations from 1 observation to 6 years of observation, with a total of 41 observations after reducing outlier data.

\section{Research Subject}

As for the subject / research is LAZ by looking at the generality of operational similarities and the same basic management. Focus of Quantitative Testing at LAZ at the national level using data from 2010-2019.

\section{Data Analysis Metode}

Data analysis was carried out quantitatively using OLS regression testing, beginning with the classical assumption test (Gujarati, 2009) which consists of a normality test, a correlation test and a test of determination.

The basic model of LAZ performance measurement is as follows:

$$
\begin{gathered}
\text { Performance }=\beta_{0}+\beta_{1} \text { Amil }+\beta_{2} \text { Size }+ \\
\beta_{3} \text { Office }+\mathrm{e}
\end{gathered}
$$

Where,

$\begin{aligned} \text { Performance }= & \text { Financial Performance } \\ & \text { which is measured by } \\ & \text { the total log of Total } \\ & \text { funds collected } \\ = & \text { Constant } \\ \beta 0 & \text { Amil funds distributed / } \\ & \text { used are measured by } \\ & \text { log data of amil } \\ & \text { distribution } \\ = & \text { LAZ size, measured by } \\ & \text { the log of total assets } \\ = & \text { number of offices c, } \\ & \text { measured by the log of } \\ \text { the number of branch } & \text { offices, service units } \\ \text { Size } \quad \text { and centers } & \text { error }\end{aligned}$

\section{RESULT}

\section{Research Sample}

The population of this study is the national LAZ Rezmi which in 2019 amounted to 24 institutions. All 24 official LAZs nationwide have their own websites. However, from this number, there are 14 LAZ that have not included financial reports on their website services. There are also LAZ which have provided annual reports but have not provided financial reports, such as Yakesma and LAZMU.

This study uses a sample of LAZ at the national level which publishes financial report data and annual reports on the 
internet. LAZ was chosen because of its competitive nature and more professional use of resources. LAZ at the national level also has a wide range of work fields so that it requires many service units / branches to reach donors and beneficiaries of zakat. Each sample has a different number of observations, with a variation of 1 to 6 observations from 2010 to 2019.

Table 2. Research Sample

\begin{tabular}{llcc}
\hline No & Criteria & Sample & Observation \\
\hline 1 & National LAZ & 24 & 48 \\
\hline 2 & $\begin{array}{l}\text { Not publish } \\
\text { financial } \\
\text { report in } \\
\text { internet }\end{array}$ & $(14)$ & - \\
\hline 3 & Sample & 10 & 48 \\
\hline 4 & Outlier & & $(7)$ \\
\hline 5 & Observations & 41 \\
\hline
\end{tabular}

To fulfill ordinary least squares requirement, 7 observations which are outliers are removed from the data leaving 41 observations. This number is relatively small but has met the minimum number of observations.

\section{Descriptive Statistic}

Presented in million, unit table 3 show performance has collected $\mathrm{Rp} 68,800$ million in average. It started at Rp 18,700 million minimum and reach Rp. 222,000 maximum. Amil Fund has Rp 10,400 million in average which is moderate expenditure for collecting fund at $\mathrm{Rp}$ 68,800 million in average. Office data shown that 40.878 is average amount for office of LAZ with minimum 1 office reported by Baitumal Muamalat.

Table 3. The descriptive statistics of the research data are shown in the table below:

\begin{tabular}{lccccc}
\hline & Mean & Max & Min & St. dev & Skewness \\
\hline Performance & 68,800 & 222,000 & 18,700 & 45,500 & 1.425 \\
\hline Amil & 10,400 & 38,300 & 1,930 & 9,210 & 1.534 \\
\hline Size & 43,900 & 189,000 & 7,070 & 44,000 & 1.930 \\
\hline Office & 40.878 & 69.000 & 1 & 2.275 & -0.346 \\
\hline Observations & 41 & & & &
\end{tabular}

\section{Correlation}

The correlation table below shows that amil funds and the size of LAZ individually have a positive relationship to LAZ performance, however the number of offices does not have a significant relationship to LAZ performance. The correlation between variable independence is significant only between amyl and LAZ size, but this relationship only has a coefficient of 0.496 . This means that independent variables are free from multicollinear relationships.

Table 4. Correlation

\begin{tabular}{|l|r|l|c|l|c|c|c|}
\hline & Performance & & Amil & & Size & & Office \\
\hline Performance & 1 & & & & & & \\
\hline & - & & & & & & \\
\hline Amil & 0.902 & $* * *$ & 1 & & & & \\
\hline & 0 & & - & & & & \\
\hline Size & 0.446 & $* * *$ & 0.496 & $* * *$ & 1 & & \\
\hline & 0.004 & & 0.001 & & - & & \\
\hline Office & 0.162 & & 0.167 & & 0.025 & & 1 \\
\hline & 0.311 & & 0.298 & & 0.877 & & - \\
\hline
\end{tabular}

Observation $=41$ 
Result

We regress performance to its factors in two models. The first model has Amil fund dan Size as independent factors. At the second model, we add amount of office as additional independent factor. We find that Amil has positive effect to Performance. It means that the increase of amil fund would increase financial performance. Size of LAZ also has positive effect to performance, but its effect lower to marginal level in the second model. It means that the raise of size of LAZ would increase financial performance in marginal level. Each model has $87.5 \%$ Adjusted $\mathrm{R}^{2}$ value, mean that those models shows that their independent variables explain $87 \%$ determinant of their performance. F statistic shows its significances at 0.000 means those models are fit to explain the factors of financial performance of LAZ.

The results are shown in the regression Table 5.

Table 5. Regression Model Result (1) Factors that Affect the Performance of Amil

$$
\text { Performance }=\beta_{0}+\beta_{1} \text { Amil }+\beta_{2} \text { Size }+\beta_{3} \text { Office }+\mathrm{e}
$$

\begin{tabular}{|c|c|c|c|c|c|c|c|}
\hline Variable & Sign exp & Coef & & Sig & Coef & & Sig \\
\hline $\mathrm{C}$ & & 7.448 & & 0.000 & 7.483 & & 0.000 \\
\hline $\log ($ Amil $)$ & + & 0.616 & $* * *$ & 0.000 & 0.656 & $* * *$ & 0.000 \\
\hline Log(Size) & + & 0.137 & **** & 0.008 & 0.110 & * & 0.056 \\
\hline $\log ($ Office $)$ & + & & & & -0.036 & & 0.308 \\
\hline Adjusted $\mathrm{R}^{2}$ & & 0.875 & & & 0.875 & & \\
\hline F-statistic & & 141.229 & & & 94.678 & & \\
\hline Prob(F-statistic) & & 0 & & & 0 & & \\
\hline
\end{tabular}

Observations: 41

\section{Discussion}

The first model shows variables contained in financial report responsible for the variation of financial performance. Both variables size and amil funds are variables presented in balances and changes of funds. In the second models, we add others variable which are not in financial report but may increase variation of financial performance. We had number of offices, number of amil (official member of LAZ) and number of volunteers which may boost the increase of financial performance. But we only had number of office data.

Amil Fund shows positives effect to financial performance. Additional amount of amil fund would raise financial performance of LAZ. Amil Fund shows the effort of LAZ to employs its human resources at optimum level, the increase of Amil fund would encourage members to exert their potential at higher level. The increase of fund also raises the use of more instruments and more ways of collecting funds, and it eventually would gain more collected funds.

While Amil fund may present brighter results. Size of LAZ also provide strong reason that it may push financial performance a higher level. Bigger size of LAZ means that LAZ has more human and others resources, bigger size also means that LAZ has more asset or better to collect more fund, bigger size also means that LAZ has better instrument to employ. However this results show marginal effect of size.

However office doesn't show significant effect to raise financial performance. This may be due to geographical reason. Some LAZ which their main office in province capital like Surabaya have their branch in municipality around Jawa Timur. While, in other side Baitulmal Muamalat which is adhered to 
bank of muamalat as its main business reported only one office in their website.

\section{CONCLUSION}

We provide evidence that that the increase of amil would increase financial performance. However size of amil zakat (LAZ) only has marginal effect o financial performance. While, number of office is not effect financial performance

\section{REFERENCE}

Kaplan, R. S. (2001). Strategic performance measurement and management in nonprofit organizations. Nonprofit management and Leadership, 11(3), 353-370.

Ahmad, I. H., \& Ma'in, M. (2014). The Efficiency of Zakat Collection and Distribution: Evidence from Two Stage Analysis. Journal of Economic Cooperation \& Development, 35(3).

Mubtadi, N. A., \& Susilowati, D. (2018). Analysis of Governance and Efficiency on Zakat Distribution: Evidence From Indonesia. International Journal of Zakat, 3(2), 1-15.

Al-Ayubi, S., \& Possumah, B. T. (2018). Examining the Efficiency of Zakat Management: Indonesian Zakat Institutions Experiences. International Journal of Zakat, 3(1), 37-55.

Rustyani, S., \& Rosyidi, S. (2018). Measurement of Efficiency and Productivity of Zakat Institutions in Indonesia using Data Envelopment Analysis and the Malmquist Productivity Index. International Journal of Zakat, 3(3), 69-82.

Risanda, A., Luthfi, F., \& Herianingrum, S. (2018). Measuring the Efficiency of BAZNAS in Managing Zakat Funds with Stochastic Frontier Approach Analysis, 2002-2016. International Journal of Zakat, 3(1), 89-107.

Farrell, M. J. (1957). The measurement of productive efficiency. Journal of the Royal Statistical Society: Series A (General), 120(3), 253-281.

\section{Achmad Hizazi \\ Universitas Jambi \\ hizazi@unja.ac.id \\ Wirmie Eka Putra \\ Universitas Jambi \\ wirmieeka@yahoo.co.id}


